\title{
Peranan Majelis Pengawas Daerah (MPD) Terhadap Pengawasan Pelaksanaan Jabatan Notaris Di Kabupaten Tegal
}

\author{
Dwikky bagus wibisono*, Umar Ma'ruf**
* Mahasiswa Program Magister (S2) Kenotariatan Fakultas Hukum UNISSULA, Semarang email : bagusdikky@gmail.com
* Dosen Fakultas Hukum UNISSULA

\begin{abstract}
Abstrak
Lembaga Kenotariatan adalah salah satu lembaga kemasyarakatan yang ada di Indonesia, lembaga ini timbul dari kebutuhan dalam pergaulan sesama manusia yang menghendaki adanya suatu alat bukti mengenai hubungan hukum keperdataan yang ada dan atau terjadi diantara mereka.

Metode pendekatan yang digunakan dalam penelitian ini adalah yuridis empiris, spesifikasi yang digunakan dalam penelitian ini bersifat deskriptif analitis, teknik pengumpulan data ini menggunakan penelitian lapangan dan studi kepustakaan.

Notaris sebagai pejabat umum dalam menjalankan jabatannya perlu diberikan perlindungan hukum, antara lain pertama untuk tetap menjaga keluhuran harkat dan martabat jabatannya termasuk ketika memberikan kesaksian dan berproses dalam pemeriksaan dan persidangan. Kedua, merahasiakan akta keterangan yang diperoleh guna pembuatan akta dan ketiga, menjaga minuta atau surat-surat yang dilekatkan pada minuta akta atau protokol Notaris dalam penyimpanan Notaris. Ketiga hal inilah yang menjadi dasar dalam Pasal 66 UUJN dalam hal pemanggilan Notaris untuk proses peradilan, penyidikan, penuntut umum atau hakim dengan persetujuan Majelis Pengawas.

Kata Kunci: Majelis Pengawas Daerah, Pengawasan,Jabatan Notaris
\end{abstract}

\begin{abstract}
s
The Notary Institution is one of the existing social institutions in Indonesia, this institution arises from the needs in the association of fellow human who wants a proof of the relationship of civil law existing and / or occur between them.

The approach method used in this research is empirical juridical, the specification used in this research is analytical descriptive, this data collection technique using field research and literature study.

Notary as a general official in carrying out his / her position needs to be given legal protection, among others, first to maintain the nobility of dignity and dignity of office including when giving testimony and proceeding in examination and trial. Second, to keep secret deeds obtained for making the deed and third, to keep the minuta or letters attached to the Minutes of Notary or Notary's protocol in the Notary's depository. These are the basic principles of Article 66 of the UUJN in the case of calling a Notary to the judicial, investigative, prosecutorial or judicial process with the approval of the Supervisory Board.
\end{abstract}

Keywords: Regional Supervisory Board,Supervision,Notary Position

\section{PENDAHULUAN}

Pembangunan hukum harus diselenggarakan sebagai bagian integral dari pembangunan nasional. Hal ini dimaksudkan untuk meningkatkan kesadaran hukum, menjamin penegakan, pelayanan dan kepastian hukum serta mewujudkan suatu tata hukum nasional yang mengabdi pada kepentingan nasional.

Dalam upaya pembinaan dan penegakkan hukum di Indonesia diperlukan perangkat peraturan perundang-undangan dan alat penegaknya. Selain itu dikenal juga adanya lembaga kemasyarakatan yang memberikan sumbangan untuk tetap tegak dan dilaksanakannya hukum dengan baik oleh anggota masyarakat, sehingga diharapkan dapat menciptakan ketertiban dan keamanan ditengahtengah masyarakat.

Lembaga Kenotariatan adalah salah satu lembaga kemasyarakatan yang ada di Indonesia, lembaga ini timbul dari kebutuhan dalam pergaulan sesama manusia yang menghendaki adanya suatu alat bukti mengenai hubungan hukum keperdataan yang ada dan atau terjadi diantara mereka ${ }^{1}$.

Terkait dengan hal ini semakin banyak kebutuhan akan jasa Notaris. Notaris sebagai abdi masyarakat mempunyai tugas melayani masyarakat dalam bidang perdata, khususnya dalam hal pembuatan akta otentik. Seperti yang dimaksud

1 G.H.S. Lumban Tobing, Peraturan Jabatan Notaris, (Jakarta: Erlangga, 1999), hal 2 
dalam Pasal 1868 Kitab Undang-undang Hukum Perdata jo Pasal satu (1) angka tujuh (7) Undangundang Nomor 30 Tahun 2004 tentang Jabatan Notaris menyebutkan bahwa:

"Akta Otentik ialah suatu akta yang didalam bentuk yang ditentukan oleh undang-undang, dibuat oleh atau dihadapan pegawai-pegawai umum yang berkuasa untuk itu di tempat dimana akta dibuatnya."

Sedangkan dalam Pasal satu (1) angka tujuh (7) Undang-undang Nomor 30 Tahun 2004 tentang Jabatan Notaris menyebutukan bahwa:

"Akta Notaris adalah akta otentik yang dibuat oleh atau dihadapan Notaris menurut bentuk dan tata cara yang ditetapkan dalam undangundang ini."

Fungsi dan peran Notaris dalam gerak pembangunan nasional yang semakin kompleks dewasa ini tentunya makin luas dan makin berkembang, sebab kelancaran dan kepastian hukum yang dijalankan oleh semua pihak makin banyak dan luas, dan hal ini tentunya tidak terlepas dari pelayanan dan produk hukum yang dihasilkan oleh Notaris. Pemerintah dan masyarakat luas tentunya mempunyai harapan agar pelayanan jasa yang diberikan oleh Notaris kepadanya benar-benar memiliki nilai dan bobot yang dapat dipertanggungjawabkan.

Notaris mempunyai peran serta dalam aktivitas menjalankan profesi hukum yang tidak dapat dilepaskan dari persoalan-persoalan mendasar yang berkaitan dengan fungsi serta peranan hukum itu sendiri, yang mana hukum diartikan sebagai kaidahkaidah yang mengatur segala kehidupan masyarakat. Tanggung jawab Notaris yang berkaitan dengan profesi hukum tidak dapat dilepaskan pada pendapat bahwa dalam melaksanakan jabatannya tidak dapat dilepaskandari keagungan hukum itu sendiri, sehingga Notaris diharapkanbertindak untuk merefleksikannya didalam pelayanannya kepada masyarakat. $^{2}$

Agar seorang Notaris benar-benar menjalankan kewenangannya, Notaris harus senantiasa melakukan tugas jabatannya menurut ukuran yangtertinggi dengan amanah, jujur, seksama, mandiri dan tidak memihak. Notaris dalam menjalankan kewenangannya tidak boleh mempertimbangkan keuntungan pribadi, Notaris hanya boleh memberi keterangan atau pendapat yang dapat dibuktikan kebenarannya, Notaris wajib

2 Wiratni Ahmadi, Pendidikan Magister Kenotariatan, (Bandung: makalah disampaikan pada pengenalan pendidikan Magister Kenotariatan Universitas Padjadjaran, 2000), hal 1-2 bersikap tulus ikhlas terhadap klien dan mempergunakan segala sumber keilmuwannya, apabila Notaris yang bersangkutan tidak menguasai bidang hukum tertentu dalam pembuatan akta, maka ia wajib berkonsultasi dengan rekan lain yang mempunyai keahlian dalam masalah yang sedang dihadapi, disamping itu Notaris juga wajib merahasiakan segala sesuatu yang diketahuinya tentang masalah klien karena kepercayaan yang telah diberikan kepadanya.

Setiap wewenang yang diberikan kepada jabatan harus ada aturan hukumnya ${ }^{3}$. Sebagai batasan agar jabatan dapat berjalan dengan baik, dan tidak berbenturan dengan wewenang jabatan lainnya. Dengan demikian jika seorang pejabat (Notaris) melakukan tindakan diluar wewenang yang telah ditentukan, dapat dikategorikan sebagai perbuatan melanggar hukum, sepertiyang dimaksud Pasal 1365 Kitab Undang-undang Hukum Perdata yang berbunyi:

"Tiap perbuatan yang melanggar hukum, yang membawa kerugian kepada seorang lain, mewajibkan orang yang karena salahnya menerbitkan kerugian itu, mengganti kerugian tersebut."

Wewenang Notaris diatur dalam Pasal 15 ayat (1) dan (2) Undang- undang Jabatan Notaris, sedangkan dalam Pasal 15 ayat (3)nya merupakan wewenang yang akan ditentukan kemudian berdasarkan aturan hukum lain yang akan datang (ius constituendum).

Mengingat peranan dan kewenangan Notaris yang sangat penting bagi lalu lintas hukum dalam kehidupan bermasyarakat, maka perilaku dan tindakan Notaris dalam menjalankan fungsi kewenangan, rentan terhadap penyalahgunaan yang dapat menimbulkan kerugian bagi masyarakat, sehingga lembaga pembinaan dan pengawasan terhadap Notaris perlu diefektifkan. Ketentuan yang mengatur tentang pengawasan bagi Notaris diatur dalam Undang-Undang Nomor 2 Tahun 2014 tentang Jabatan Notaris. Ketentuan ini merupakan salah satu upaya untuk mengantisipasi kelemahan dan kekurangan dalam sistem pengawasan terhadap Notaris, sehingga diharapkan dalam menjalankan profesi jabatannya, Notaris dapat lebih meningkatkan kualitas pelayanan kepada masyarakat.

Sebelum berlaku Undang-Undang Nomor 2 Tahun 2014 berlaku juga Undang-Undang Nomor 30 Tahun 2004 tentang Jabatan Notaris,

3 Philipus M.Hadjon \& Tatik Sri Djatmiati, Tentang Wewenang, (Surabaya:Majalah Yuridika, Edisi V,1997), hal 1 
pengawasan, pemeriksaan, dan penjatuhan sanksi terhadap Notaris dilakukan oleh badan peradilan yang ada pada waktu itu.Sebagaimana pernah diatur dalam Pasal 140 Reglement op de Rechtelijke Organisatie enHet Der Justitie (Stb. 1847 No.23), Pasal 96 Reglement Buitengewesten, Pasal 3 Ordonantie Buitengerechtelijke Verrichtingen Lembaran Negara1946Nomor 135, dan Pasal 50 Peraturan Jabatan Notaris. Kemudian Pengawasan terhadap Notaris dilakukan oleh Peradilan Umum dan Mahkamah Agung sebagaimana tersebut dalam Pasal 32 dan 54 Undang-undang Nomor 13 Tahun 1965 tentang Pengadilan dalam Likungan Peradilan Umum dan Mahkamah Agung, kemudian dibuat pula Surat Edaran Mahkamah Agung Republik Indonesia Nomor 2 Tahun 1984 tentang Tata Cara Pengawasan Terhadap Notaris, Keputusan Bersama Ketua Mahkamah Agung dan Menteri Kehakiman Nomor KMA/006/SKB/VII/1987 tentang Tata Cara Penindakan dan Pembelaan Diri Notaris, dan terakhir dalam Pasal 54 Undang-undang Nomor 8 Tahun 2004 tentang Peradilan Umum.

Pada tahun 1999 sampai dengan tahun 2001 dilakukan perubahan terhadap Undang-undang Dasar (UUD) 1945, dengan amandemen tersebut telah pula merubah Kekuasaan Kehakiman. Dalam Pasal 24 ayat (2) Undang- undang Dasar (UUD) 1945 menegaskan bahwa Kekuasaan Kehakiman dilakukan oleh institusi Mahkamah Agung dan badan peradilan yang berada di bawahnya. Sebagai tindak lanjut dari perubahan tersebut Undangundang Nomor 48 Tahun 2009 tentang Pokokpokok Kekuasaan Kehakiman yang dalam Pasal 18 ditegaskan bahwa penyelenggaraan kekuasaan kehakiman oleh sebuah Mahkamah Agung dan badan peradilan yang berada di bawahnya dalam lingkungan Peradilan Umum, Peradilan Agama, Peradilan Militer, Peradilan Tata Usaha Negara dan oleh sebuah Mahkamah Konstitusi, dalam Pasal 1 Undang-undang Nomor 5 Tahun 2004 tentang PerubahanAtasUndang-undang Nomor 14 Tahun 1985 tentang Mahkamah Agung, ditegaskan bahwa Mahkamah Agung sebagai pelaku salah satu kekuasaan kehakiman.

Pada tahun 2004 dibuat Undang-undang Nomor 8 Tahun 2004, dalam Pasal 5 ayat (1) ditegaskan bahwa pembinaan tehnis peradilan, organisasi, administrasi, dan finansial pengadilan dilakukan oleh Mahkamah Agung sesuai dengan isi Keputusan Presiden Nomor 21 Tahun 2004 mengenai Pengalihan Organisasi, Administrasi dan Finansial di Lingkungan Umum Peradilan Tata Usaha Negara dan Peradilan Agama ke Mahkamah Agung.

Dengan adanya pengalihan kewenangan tersebut, Notaris diangkat oleh pemerintah dalam hal ini Departemen Hukum Dan Hak Asasi Manusia, kemudian tentang pengawasan terhadap Notaris yang diatur dalam Pasal 54 Undang-undang Nomor 8 Tahun 2004 dicabut oleh Pasal 91 Undangundang Jabatan Notaris.

Sejak kehadiran institusi Notaris di Indonesia, pengawasan terhadap Notaris dilakukan oleh lembaga peradilan dan pemerintah, tujuan dari pengawasan agar para Notaris ketika menjalankan tugas jabatannya memenuhi semua persyaratan yang berkaitan dengan pelaksanaan tugas jabatan Notaris, demi untuk pengamanan kepentingan masyarakat. Karena Notaris diangkat oleh pemerintah, bukan untuk kepentingan diri Notaris sendiri melainkan untuk kepentingan masyarakat yang dilayaninya ${ }^{4}$.

Notaris dihadirkan untuk melayani kepentingan masyarakat yang membutuhkan alat bukti berupa akta otentik sesuai permintaankepadaNotaris. Sehingga tanpa adanya masyarakat yang membutuhuhkan Notaris, maka Notaris tidak ada gunanya. Meskipun demikian tidak berati dengan bergantinya instansi yang melakukan pengawasan Notaris tidak akan terjadi pelanggaran-pelanggaran yang dilakukan oleh Notaris, karena meskipun pengawasan yang dilakukan Majelis Pengawas Notaris, betapapun ketatnya pengawasan yang dilakukan Majelis Pengawas Notaris, tidak mudah melakukan pengawasan tersebut. Hal ini kembali kepada Notaris sendiri dengan kesadaran dan penuh tanggung jawab dalam tugas jabatannya mengikuti atau berdasarkan aturan hukum yang berlaku.

Peranan Majelis Pengawas Notaris adalah melaksanakan pengawasan terhadap Notaris, supaya dalam menjalankan tugas jabatannya tidak menyimpang dari kewenangannya dan tidak melanggar peraturan perundang- undangan yang berlaku, disamping itu juga melakukan pengawasan, pemeriksaan dan menjatuhkan sanksi terhadap Notaris, sedangkan fungsi Majelis Pengawas Notaris adalah agar segala hak dan kewenangan maupun kewajiban yang diberikan kepada Notaris dalam menjalankan tugas jabatannya sebagaimana yang diberikan oleh peraturan perundang-undangan yang berlaku, senantiasa dilakukan diatas jalur yang telah ditentukan, bukan saja jalur hukum, tetapi juga atas dasar moral dan etika demi terjaminnya perlindungan hukum dan kepastian hukum bagi pihak yang membutuhkannya. Tidak kalah penting juga peranan masyarakat untuk mengawasi dan

\footnotetext{
${ }^{4}$ G.H.S. Lumban Tobing, op cit, hal 301
} 
senantiasa melaporkan tindakan Notaris yang dalam melaksanakantugasjabatannya tidak sesuai dengan aturan hukum yang berlaku kepada Majelis Pengawas Notaris setempat. Dengan adanya laporan seperti ini dapat mengeliminasi tindakan Notaris yang tidak sesuai dengan aturan hukum pelaksanaan tugas jabatan Notaris.

Di dalam ketentuan Pasal 67 sampai dengan Pasal 81 Undang-undang Jabatan Notaris (UUJN) terdapat sarana kaidah-kaidah hukum untuk mengawasi Notaris yang meliputi perilaku Notaris dan pelaksanaan jabatan Notaris.

Dalam Pasal 67 Undang-undang Jabatan Notaris ditentukan bahwa yang melakukan pengawasan terhadap Notaris adalah Menteri, Dalam melaksanakan tugas pengawasan tersebut Menteri membentuk Majelis Pengawas Notaris yang mana masing-masing Majelis Pengawas Notaris tersebut terdiri dari 9 (sembilan) orang, terdiri dari unsur :

1. Pemerintah sebanyak tiga (3) orang:

2. Organisasi Notaris sebanyak tiga (3) orang; dan

3. Ahli/Akademik sebanyak tiga (3) orang.

Sedangkan dalam Pasal 68 Undang-undang Jabatan Notaris menyebutkan, bahwa Majelis Pengawas sebagaimana dimaksud dalam Pasal 67 ayat (2) terdiri atas:

1. Majelis PengawasDaerah;

2. Majelis PengawasWilayah;

3. Majelis PengawasPusat.

Dalam Pasal 3 ayat (1), Pasal 4 ayat (1) dan Pasal 5 ayat (1) Peraturan Menteri ditentukan pengusulan Anggota Majelis Pengawas. Ketentuan Pasal 3 ayat (1) menentukan pengusulan Anggota Majelis Pengawas Daerah (MPD) terdiri atas:

1. Unsur pemerintah oleh Kepala Divisi Pelayanan Hukum Kantor Wilayah;

2. Unsur organisasi Notaris oleh Pengurus Daerah Ikatan Notaris Indonesia;

3. Unsur ahli/akademis oleh dosen/staf pengajar fakultas hukum atau perguruan tinggi setempat.

Majelis Pengawas Daerah (MPD) dibentuk dan berkedudukan di kabupaten atau di kota (Pasal 69 ayat [1] Undang-undang Jabatan Notaris). Ketentuan Pasal 4 ayat (1) menentukan pengusulan Anggota Majelis Pengawas Wilayah (MPW) terdiri atas:

a. Unsur pemerintah oleh Kepala Kantor Wilayah;

b. Unsur organisasi Notaris oleh Pengurus Wilayah Ikatan Notaris Indonesia;

c. Unsur ahli/akademis oleh dosen/staf pengajar fakultas hokum atau perguruan tinggi setempat.

Majelis Pengawas Wilayah (MPW) dibentuk dan berkedudukan di ibukota propinsi (Pasal 72 ayat (1) Undang-undang Jabatan Notaris).
Ketentuan Pasal 5 ayat (1) menentukan pengusulan Anggota Majelis Pengawas Pusat (MPP) terdiri atas:

1. Unsur pemerintah oleh Direktur Jenderal Administrasi HukumUmum;

2. Unsur organisasi Notaris oleh Pengurus Pusat Ikatan Notaris Indonesia;

3. Unsur ahli/akademis oleh dekan fakultas hokum universitas yang menyelenggarakan program magisterkenotariatan.

Majelis Pengawas Pusat (MPP) dibentuk dan berkedudukan di ibukota negara (Pasal 76 ayat [1] Undang-undang Jabatan Notaris).Penulis hendak mengamati peranan dan fungsi Majelis Pengawas di tingkat Wilayah terhadap pelaksanaan tugas jabatan Notaris, karena selain Majelis Pengawas Pusat, Majelis Pengawas Wilayah juga mempunyai kewenangan untuk mengadakan dan atau melakukan pemeriksaan kepada Notaris yang melakukan pelanggaran baik yang berupa kode etik Notaris maupun ketentuan dalam peraturan perundang-undangan yang berlaku, sehingga dapat dijatuhkan sanksi. Untuk memperjelas hal tersebut diatas, maka akan ditinjau lebih lanjut tentang pengawasan Notaris di wilayah Propinsi Jawa Tengah dan bagaimana kinerja Majelis Pengawas Wilayah dalam menyikapi kendala-kendala yang muncul di lapangan berkaitan dengan tugas jabatan Notaris.

Berdasarkan pada latar belakang diatas, penulis tertarik untuk menulis tesis dengan judul Peranan Majelis Pengawas Daerah (MPD) Terhadap Pengawasan Pelaksanaan Jabatan Notaris di Kabupaten Tegal.

\section{Metode Penelitian}

Metode pendekatan yang digunakan dalam penelitian ini adalah yuridis empiris yaitu dengan melakukan penelitian secara timbal balik antara hukum dengan lembaga non doktrinal yang bersifat empiris dalam menelaah kaidah-kaidah hukum yang berlaku dimasyarakat.

Dalam penelitian ini dititik beratkan pada langkah-langkah pengamatan dan analisa yang bersifat empiris. Pendekatan penelitian akan dilakukan pada Kantor Wilayah Departemen Hukum dan Hak Asasi Manusia, Kantor Notaris di Propinsi Daerah Istimewa Yogyakarta, dan unsur akademis dari fakultas hukum universitas yang menyelenggarakan program magister kenotariatan, dimana hal ini sebagai bahan penelitian. Sedangkan dari segi yuridis ditekankan pada doktrinal hukum, melalui peraturan-peraturan yangberlaku.

Spesifikasi yang digunakan dalam penelitian ini bersifat deskriptif analitis, yaitu dimaksudkan untuk 
memberi data yang seteliti mungkin tentang suatu keadaan atau gejala-gejala lainnya ${ }^{5}$, karena penelitian inidiharapkan memberi gambaran secara rinci, sistematis dan menyeluruh mengenai peraturan perundang-undangan yang berlaku dikaitkan dengan teori-teori hukum dan praktek pelaksanaan hukum positif. Disamping itu bertujuan memberikan gambaran dan menganalisa permasalahan yang ada, dimana penelitian ini akan memaparkan segala hal yang berhubungan dengan pelaksanaan tugas pengawasan terhadap Notaris dalam kekuasaan Departemen Hukum dan Hak Asasi Manusia, serta peranan dan fungsi Majelis Pengawas Daerah Kabupaten Tegal dan Majelis Pengawas Wilayah Tegal terhadap pelaksanaan tugas jabatan Notaris.

Dalam Teknik Pengumpulan Data ini menggunakan penelitian lapangan dan studi kepustakaan. Penelitian lapangan artinya: Penelitian yang dilakukan dengan cara mengamati langsung terhadap para pihak yang berkompeten melalui: 1) Wawancara/Interview, untuk memperoleh informasi dengan bertanya langsung pada yang diwawancarai. ${ }^{6}$ Interview yang digunakan dalam penelitian ini adalah interview bebas terpimpin, yaitu dengan mempersiapkan terlebih dahulu pertanyaanpertanyaan sebagai pedoman, tetapi tidak menutup kemungkinan adanya variasi pertanyaan sesuai dengan situasi ketika wawancara berlangsung. Wawancara akan dilakukan dengan Notaris dan pejabat yang berwenang di lingkungan Wilayah Departemen Hukum dan Hak Asasi Manusia. 2) Kuisioner adalah daftar pertanyaan yang disusun secara tertulis berdasarkan proposal penelitian. ${ }^{7}$ Dalam hal data yang diperoleh dari wawancara dirasakan kurang, maka dengan kuisioner yang dipergunakan, diharapkan pertanyaanya harus dijawab dengan memberikan keterangan yang sejelas mungkin. 3) Studi Kepustakaan artinya pengumpulan data-data yang diperoleh melalui bahan pustaka yang berisikan informasi tentang bahan primer. Studi Kepustakaan diperoleh dengan mempelajari literatur-literatur yang berhubungan dengan obyek dan permasalahan yang diteliti. Studi Kepustakaan tersebut untuk selanjutnya merupakan landasan teori dalam mengadakan penelitian lapangan serta pembahasan dan analisa data.

Studi Kepustakaan dalam penelitian ini meliputi: 1) Bahan hukum primer yang berupa ketentuan perundang-undangan, antara lain: Kitab Undang-

5 Soerjono Soekanto \& Sri Mamuji, Penelitian Hukum Normatif suatu tinjauan singkat

(Jakarta:RajaGrafindo Persada, 2001), hal 43

${ }^{6}$ Ronny Hanitijo Soemutro, op cit, hal 57

${ }^{7}$ Abdul Kadir Muhammad, op cit, hal 89 undang Hukum Perdata; Peraturan Jabatan Notaris (Reglement-Stbl.1860-3); Undang-undang Jabatan Notaris (Undang-undang Nomor 30 Tahun 2004); 2) Bahan hukum sekunder berupa tulisan-tulisan para ahli di bidang hukum dan bidang-bidang yang terkait dengan permasalahan yang diteliti.

Data yang telah dikumpulkan baik dari penelitian lapangan maupun penelitian kepustakaan akan dianalisa dengan metode analisis data kualitatif yaitu: 1) Analisis: Metode analisis dengan memilih data yang menggambarkan keadaan yang sebenarnya di lapangan, analisis menggunakan cara berpikir induktif, yaitu menyimpulkan hasil penelitian dari hal-hal yang sifatnya khusus ke hal-hal yang sifatnya umum; 2) Kualitatif: Metode analisis data yang mengelompokkan dan menyeleksi data yang diperoleh dari penelitian lapangan menurut kualitas dan kebenarannya, kemudian dihubungkan dengan teori-teori yang diperoleh dari studi kepustakaan sehingga diperoleh gambaran dan pemahaman yang sistematis dan menyeluruh untuk menjawab masalah yang diteliti.

\section{Hasil Penelitian dan Pembahasan}

Mengenai kewenangan Majelis Pengawas (Daerah, Wilayah, dan Pusat ) ini, ada satu kewenangan Majelis Pengawas yang perlu untuk diluruskan sesuai aturan hukum yang berlaku, yaitu atas laporan Majelis Pemeriksa jika menemukan suatu tindak pidana dalam melakukan pemeriksaan terhadap notaris, maka majelis pengawas akan melaporkannya kepada pihak yang berwenang. Substansi Pasal ini telah menempatkan Majelis Pengawas Notaris sebagai pelapor tindak pidana. ${ }^{8}$

Menurut Pasal 1 angka 24 Kitab Undang Undang Hukum Acara Pidana (KUHAP) bahwa laporan adalah pemberitahuan yang disampaikan oleh seseorang karena hak atau kewajiban berdasarkan undang-undang kepada pejabat berwenang tentang telah atau sedang atau diduga akan terjadinya peristiwa pidana. Berdasarkan isi Pasal tersebut, bahwa syarat untuk menjadi pelapor, yaitu: 1) Seorang (satu orang/ perseorangan); dan 2) Ada hak dan kewajiban berdasarkan undangundang.

Meskipun MPD mempunyai wewenang untuk menerima laporan dari masyarakat dan dari notaris lainnya dan menyelenggarakan sidang untuk memeriksa adanya dugaan pelanggaran pelaksanaan jabatan notaris, tapi tidak diberi kewenangan untuk menjatuhakan sanksi apapun. Dalam hal ini, MPD hanya berwenang untuk melaporkan hasil sidang dan

\footnotetext{
${ }^{8}$ Majalah Renvoi Nomor 10.22. II tanggal 3 Maret 2005, hal 37
} 
pemeriksaannya kepada MPW dengan tembusan kepada pihak yang melaporkan, notaris yang bersangkutan, Majelis Pengawas Pusat, dan organisasi notaris;

Majelis Pengawas Daerah (MPD) mempunyai kewenangan khusus yang tidak dipunyai oleh MPW dan MPP, yaitu sebagaimana yang tersebut dalam Pasal 66 UUJN, bahwa MPD berwenang untuk memeriksa Notaris sehubungan dengan permintaan penyidik, penuntut umum atau hakim untuk mengambil fotokopi minuta atau surat-surat lainnya yang dilekatkan pada minuta atau dalam protokol Notaris dalam penyimpanan Notaris, juga pemanggilan Notaris yang berkaitan dengan akta yang dibuatnya atau dalam protokol Notaris yang berada dalam penyimpanan Notaris.

Hasil akhir pemeriksaan MPD yang dituangkan dalam bentuk Surat Keputusan, berisi dapat memberikan persetujuan atau menolak permintaan penyidik, penuntut umum atau hakim.Ketika UUJN diundangkan, para Notaris berharap dapat perlindungan yang proporsional kepada para Notaris ketika dalam menjalankan tugas jabatan sebagai Notaris, setidaknya atau salah satunya melalui atau berdasarkan ketentuan atau mekanisme-implementasi Pasal 66 UUJN yang dilakukan MPD, juga setidaknya ada pemeriksaan yang adil, transparan, beretika dan ilmiah ketika MPD memeriksa Notaris atas permohonan pihak lain (kepolisian, kejaksaan, pengadilan), tapi hal tersebut sangat sulit untuk dilaksanakan, karena para anggota MPD yang terdiri unsur-unsur yang berbeda, yaitu 3 (tiga) orang Notaris, 3 (tiga) orang akademis dan 3 (tiga) orang birokrat (Pasal 67 ayat (3) UUJN, yang berangkat dari latar belakang yang berbeda, sehingga tidak ada persepsi yang sama ketika memeriksa Notaris. Contohnya mengenai fokus pemeriksaan yang dilakukan oleh MPD:

Apakah objek pemeriksaan MPD, berkaitan dengan Notaris (orang yang melaksanakan Jabatan Notaris) atau akta Notaris? Dalam pemeriksaan MPD tidak bisa membedakan antara Notaris sebagai objek dan akta sebagai objek. Jika MPD menempatkan Notaris sebagai objek, maka MPD berarti akan memeriksa tindakan atau perbuatan Notaris dalam menjalankan tugas jabatannya, yang pada akhirnya akan menggiring Notaris pada kualifikasi turut serta atau membantu terjadinya suatu tindak pidana.

Sudah tentu tindakan seperti ini tidak dapat dibenarkan, karena suatu hal yang sangat menyimpang bagi Notaris dalam menjalankan tugas jabatannya untuk turut serta atau membantu melakukan atau menyarankan dalam akta untuk terjadinya suatu tindak pidana dengan para pihak/penghadap. Dalam kaitan ini tidak ada aturan hukum yang membenarkan MPD mengambil tindakan dan kesimpulan yang dapat mengkualifikasikan Notaris turut serta atau membantu melakukan suatu tindak pidana bersamasama para pihak/penghadap. MPD bukan instansi pemutus untuk menentukan Notaris dalam kualifikasi seperti itu.

Dalam tataran aturan hukum yang benar bahwa MPD harus menempatkan akta Notaris sebagai objek, karena Notaris dalam menjalankan tugas jabatannya berkaitan untuk membuat dokumen hukum, berupa akta sebagai alat bukti tertulis yang berada dalam ruang lingkup hukum perdata, sehingga menempatkan akta sebagai objek harus dinilai berdasarkan aturan hukum yang berkaitan dengan pembuatan akta, dan jika terbukti ada pelanggaran, maka akan dikenai sanksi sebagaimana yang tersebut dalam Pasal 84 dan 85 UUJN.Dengan demikian bukan wewenang MPD jika dalam melakukan tugasnya mencari unsur-unsur (pidana) untuk menggiring Notaris dengan kualifikasi turut serta atau membantu melakukan suatu tindakan atau perbuatan pidana.

Adakah batasan MPD dalam melakukan pemeriksaan? Bahwa batasan MPD dalam melakukan pemeriksaan, yaitu dengan objeknya akta Notaris.

Menempatkan akta sebagai objek, maka batasan MPD dalam melakukan pemeriksaan akan berkisar pada:

a) kekuatan pembuktian lahiriah akta Notaris.. Dalam memeriksa aspek lahiriah dari akta Notaris, maka MPD harus dapat membuktikan otensitas akta Notaris tersebut. MPD harus melakukan pembuktian terbalik untuk menyangkal aspek lahiriah dari akta Notaris. Jika MPD tidak mampu untuk membuktikannya, maka akta tersebut harus dilihat "apa adanya", bukan dilihat "ada apa".

b) kekuatan pembuktian formal akta Notaris., Dalam hal ini MPD harus dapat membuktikan ketidakbenaran apa yang dilihat, disaksikan dan didengar oleh Notaris, juga harus dapat membuktikan ketidak benaran pernyataan atau keterangan para pihak yang diberikan/disampaikan di hadapan Notaris. Dengan kata lain MPD tetap harus melakukan pembuktian terbalik untuk menyangkal aspek formal dari akta Notaris. Jika MPD tidak mampu untuk membuktikannya, maka akta tersebut harus diterima oleh siapapun termasuk oleh MPD sendiri.

c) kekuatan pembuktian materil akta Notaris, Dalam kaitan ini MPD harus dapat membuktikan, bahwa Notaris tidak menerangkan atau menyatakan yang sebenarnya dalam akta (akta 
pejabat), atau para pihak yang telah benar berkata (di hadapan Notaris) menjadi tidak berkata benar. MPD harus melakukan pembuktian terbalik untuk menyangkal aspek materil dari akta Notaris. Jika MPD tidak mampu untuk membuktikannya, maka tersebut akta tersebut benar adanya.

Dengan demikian aspek mana yang akan dibuktikan secara terbalik oleh MPD ketika memeriksa Notaris? Maka MPD dibebani pembuktian sebagaimana diatur dalam Pasal 138 HIR (Pasal 164 Rbg, $148 \mathrm{Rv}$ ), sebelum memutuskan apakah Notaris yang diperiksa tersebut telah melanggar salah satu atau ketiga aspek tersebut.

Ketiga aspek tersebut di atas merupakan kesempurnaan akta Notaris sebagai alat bukti. Sehingga siapapun (hakim, jaksa, kepolisian, bahkan Notaris dan MPD sendiri) terikat untuk menerima akta Notaris "apa adanya", dan siapapun tidak dapat menafsirkan lain atau menambahkan/meminta alat bukti lain untuk menunjang akta Notaris, sebab jika akta Notaris tidak dinilai sebagai alat bukti yang sempurna, akan menjadi tidak ada gunanya undangundang menunjuk Notaris sebagai Pejabat Umum untuk membuat akta otentik sebagai alat bukti yang sempurna, jika ternyata siapapun saja dengan semaunya dan seenaknya atau tanpa dasar hukum yang jelas mengenyampingkan akta Notaris sebagai alat bukti yang sempurna. Oleh karena itu jika ada sesama Notaris saling menyalahkan atau menjelekkan akta yang dibuat oleh Notaris lainnya, hal ini menujukkan bahwa Notaris yang bersangkutan tidak mengerti makna akta Notaris sebagai alat bukti yang sempurna.

Jika anggota MPD yang berasal dari Notaris memahami dengan benar pelaksanaan tugas jabatan Notaris sesuai UUJN, maka akan mengerti untuk menempatkan fokus pemeriksaan Notaris dengan objek pada akta Notaris. Jika anggota MPD yang berasal dari Notaris memahami dengan benar lembaga kenotariatan sudah pasti akan tetap menjaga jabatan Notaris sebagai jabatan kepercayaan. Untuk mengerti dan memahami dunia Notaris, para Notaris sebelumnya harus menimba ilmu kenotariatan kurang lebih selama 2 (dua) tahun, sehingga anggota MPD yang bukan dari Notaris untuk dapat memahami dunia Notaris, juga terlebih dahulu untuk menimba ilmu dunia Notaris secara komprensip. Jika ini dapat dilakukan maka akan ada persepsi yang sama ketika memeriksa Notaris.

Jika ternyata MPD memutuskan (berdasarkan Surat Keputusan yang dibuat oleh MPD) untuk meloloskan Notaris untuk diperiksa oleh pihak penyidik, kejaksaan atau di pengadilan, sebagai implementasi Pasal 66 UUJN, tidak ada kemungkinan untuk mengajukan keberatan untuk dilakukan pemeriksaan ke instansi majelis yang lebih tinggi, seperti ke Majelis Pemeriksa Wilayah (MPW) atau ke Majelis Pemeriksa Pusat (MPP), karena mekanisme seperti itu, khusus untuk pelaksanaan Pasal 66 UUJN tidak ditentukan atau tidak ada upaya hukum keberatan atau banding.

Meskipun demikian jika Notaris diloloskan oleh MPD, maka Notaris yang bersangkutan dapat mengajukan upaya hukum ke Pengadilan Tata Usaha Negara (PTUN) dengan objek gugatan yaitu surat MPD yang meloloskan Notaris tersebut, hal ini akan menjadi sengketa tata usaha negara. Hal tersebut dapat dilakukan karena MPD berkedudukan sebagai badan atau Jabatan Tata Usaha Negara (TUN) dan telah mengeluarkan suatu keputusan sebagai Keputusan Tata Usaha Negara.

Hasil akhir dari pemeriksaan yang dilakukan oleh MPD berupa Surat Keputusan (yang merupakan suatu penetapan tertulis). Jika dikaji ternyata Surat Keputusan tersebut bersifat konkrit, individual, final dan menimbulkan akibat hukum. Konkrit artinya objek yang diputuskan bukan suatu hal yang abstrak, tapi dalam hal ini objeknya yaitu akta tertentu yang diperiksa oleh MPD yang dibuat oleh Notaris yang bersangkutan.

Individual artinya keputusan tidak ditujukan kepada umum atau kepada semua orang, tapi kepada nama Notaris yang bersangkutan. Final artinya sudah definitif, yang tidak memerlukan persetujuan dari pihak lain atau insitusi atasannya, sehingga hal ini dapat menimbulkan akibat hukum tertentu bagi Notaris yang bersangkutan. Ketentuan semacam ini hanya berlaku untuk Surat Keputusan MPD sebagai penerapan dari Pasal 66 UUJN.

Berdasarkan uraian di atas, maka sangat tidak tepat jika MPD yang berkedudukan sebagai Badan Tata Usaha Negara kewenangannya dikebiri dengan batasan waktu seperti yang tersebut dalam Pasal 6 dan 12 Peraturan Menteri tersebut, karena seharusnya jika seorang Notaris merasa berkeberatan dan tidak memperoleh pemeriksaan yang transparan dari MPD, dan atas keputusan MPD dapat dijadikan sebagai objek sengketa tata usaha Negara di Pengadilan Tata Usaha Negara, tapi dalam Peraturan Menteri tersebut, hak Notaris telah dihilangkan, dan hal ini bertentangan dengan Undang-undang Nomor 5 Tahun 1986, tentang Peradilan Tata Usaha Negara juncto Undang-undang Republik Indonesia Nomor 9 tahun 2004 Tentang Perubahan Atas Undang-undang Nomor 5 Tahun 1986 Tentang Peradilan Tata Usaha Negara

Dengan demikian tindakan MPD yang memutuskan meloloskan Notaris untuk diperiksa oleh pihak lain sebagai pelaksanaan Pasal 66 UUJN, jika 
tidak memuaskan bagi Notaris atau Notaris yang bersangkutan berkeberatan dengan alasan yang diketahui oleh Notaris sendiri, maka Notaris yang bersangkutan dapat menggugat MPD ke Pengadilan Tata Usaha Negara. Surat Keputusan MPD tersebut merupakan objek gugatan di Pengadilan Tata Usaha Negara.

\section{PENUTUP}

\section{Kesimpulan}

Berdasarkan uraian dan bahasan sebelumnya, maka dapatlah ditarik kesimpulan sebagai berikut:

1. Pelaksanaan Tugas Pengawasan Terhadap Notaris Majelis Pengawas Daerah merupakan amanat Undang-undang Jabatan Notaris, khususnya Pasal 67 Ayat (1) dan (2) yang menyatakan bahwa menteri berwenang dalam mengawasi notaris dan dalam melaksanakan pengawasannya menteri membentuk majelis pengawas. "Notaris adalah pejabat urnum yang berwenang untuk membuat akta otentik dan kewenangan lainnya sesuai dengan ketentuan yang berlaku. Sebagai pejabat umum, notaris diangkat dan diberhentikan oleh menteri, dalam hal ini menteri yang mempunyai tugas dan tanggung jawab di bidang kenotariatan adalah Menteri Hukum dan HAM. Oleh karenanya pengawasan yang dilakukan sebelum berlakunya Undang-undang Jabatan Notaris adalah bersifat preventif dan represif, akan tetapi setelah berlakunya Undang-undang Jabatan Notaris maka pengawasan yang dilakukan lebih bersifat preventif dan kuratif lagi.

2. Peranan dan fungsi Majelis Pengawas Daerah terhadap Pelaksanaan tugas Jabatan Notaris melakukan tugasnya selalu memperhatikan dan melihat relevansi serta urgensi seorang Notaris dipanggil sebagai saksi maupun sebagai tersangka dengan pengambilan minuta atau foto copynya maupun surat-surat yang dilekatkan pada minuta tersebut untuk proses peradilan, penyidikan atau penuntut umum. Dengan persetujuan tersebut mempunyai arti bahwa dengan tidak adanya persetujuan maka hal tersebut tidak dapat dilakukan.

Notaris sebagai pejabat umum dalam menjalankan jabatannya perlu diberikan perlindungan hukum, antara lain pertama untuk tetap menjaga keluhuran harkat dan martabat jabatannya termasuk ketika memberikan kesaksian dan berproses dalam pemeriksaan dan persidangan.
Kedua, merahasiakan akta keterangan yang diperoleh guna pembuatan akta dan ketiga, menjaga minuta atau surat-surat yang dilekatkan pada minuta akta atau protokol Notaris dalam penyimpanan Notaris. Ketiga hal inilah yang menjadi dasar dalam Pasal 66 UUJN dalam hal pemanggilan Notaris untuk proses peradilan, penyidikan, penuntut umum atau hakim dengan persetujuan Majelis Pengawas.

\section{Saran}

Adapaun saran yang dapat penulis sampaikan melalui artikel jurnal ini adalah sebagai berikut:

1. Hendaknya Majelis Pengawas yang mengawasi Notaris dalam menjalankan tugas dan jabatannya adalah pengawas yang memiliki pengetahuan dan mengerti tentang kenotariatan khususnya dalam pembuatan akta otentik dan juga memiliki integritas moral yang tinggi.

2. Hendaknya Majelis Pengawas Notaris yang telah dibentuk dan diangkat sesuai dengan amanat Undang-undang Jabatan Notaris dapat rnenjalankan tugasnya dengan baik dan dengan keikhlasan untuk mengawasi Notaris sehingga nantinya Notaris bisa memiliki integritas moral yang tinggi dalam menjabat sebagai pejabat umum. Dan melaksanakan tugas dan jabatannya benar-benar memperhatikan nilai luhur, martabat dan etika serta mematuhi peraturan perundangundangan yang berlaku.

3. Dengan adanya perlindungan hukum dilaksanakan terhadap Notaris, hendaknya bisa menjadi seorang pejabat umum yang profesional dalam jabatannya khususnya dalam pembuatan akta yang bersifat otentik.

\section{Daftar Pustaka}

G.H.S. Lumban Tobing, Peraturan Jabatan Notaris, (Jakarta: Erlangga, 1999).

Majalah Renvoi Nomor 10.22. II tanggal 3 Maret 2005.

Soerjono Soekanto \& Sri Mamuji, Penelitian Hukum Normatif suatu tinjauan singkat (Jakarta: Raja Grafindo Persada, 2001).

Philipus M.Hadjon \& Tatik Sri Djatmiati, Tentang Wewenang, (Surabaya: Majalah Yuridika, Edisi V, 1997).

Wiratni Ahmadi, Pendidikan Magister Kenotariatan, (Bandung: makalah disampaikan pada pengenalan pendidikan Magister Kenotariatan Universitas Padjadjaran, 2000). 